\title{
Логіко-лінгвістична модель оцінювання стану воєнно-економічної безпеки держави
}

\author{
Олег Семененко * А; Ірина Чернишова А; Людмила Добровольська ${ }^{\text {B; }}$ \\ Костянтин Харитонов ${ }^{C}$; Іван Мотрунич ${ }^{D}$ \\ А Центральний науково-дослідний інститут Збройних Сил України, проспект Повітрофлотський, 28, м. Київ, 03049, Україна \\ в Національний авіаційний університет, проспект Любомира Гузара, 1, Київ, 03058, Україна \\ ' Командування військ зв'язку та кібербезпеки Збройних Сил України, проспект Повітрофлотський, 6, м. Київ, 03168, Україна \\ ' Центр забезпечення службової діяльності МО України та ГШ зС України, проспект Повітрофлотський, 6, м. Київ, 03168, Україна
}

Received: October 01, 2020 | Revised: October 20, 2020 | Accepted: October 31, 2020

JEL Classification: B23, B41, C20.

DOI: $10.33445 /$ sds.2020.10.5.3

\begin{abstract}
Анотація
Сучасні тенденції розвитку теорії і практики формування національних інтересів держави та оцінювання стану їх захищеності показує, що одними із визначальних елементів сучасного безпекового середовища для будь-якої країни $\epsilon$ стан розвитку їх воєнної та економічної складової. Міцний зв'язок цих двох складових національної безпеки України дозволяє їх поєднати в єдине поняття - воєнно-економічна безпека країни. Сьогодні, воєнно-економічну безпеку можна розглядати як стан захищеності національного економіки держави від зовнішніх та внутрішніх загроз, за якого воно здатна задовольняти економічні потреби воєнної організації для ї̈ будівництва, утримання та подальшого розвитку з метою забезпечення необхідного рівня захисту національних інтересів України в цілому. У статті авторами наведено один із можливих підходів до оцінювання стану воєнно-економічної безпеки держави за наявності невизначеної сукупності вхідних та вихідних параметрів за допомогою використання методу нечітких множин та логіколінгвістичного підходу. Застосування такого підходу надасть можливості сформувати загальні оцінки стану воєнно-економічної безпеки держави з метою прийняття відповідних управлінських рішень щодо подальшого її розвитку, а також застосування теорії нечітких множин під час оцінювання дозволить оцінювати чутливість та стабільність прийнятих рішень до можливих змін вхідних даних.
\end{abstract}

Ключові слова: воєнна безпека, економічна безпека, воєнно-економічна безпека, оборонні компоненти, лінгвістична шкала, лінгвістична змінна, інтегральна функція, логіколінгвістичний підхід.

\section{Постановка проблеми}

$\begin{array}{llll}\text { Воєнна та економічна безпеки } € & \text { вона може задовольняти економічні потреби } \\ \text { невід'ємними складовими національної } & \text { воєнної організації, воєнно-промислового та } \\ \text { безпеки України. Тому безпосередній зв'язок } & \text { науково-технічного комплексів для їх стійкого } \\ \text { воєнної та економічної складових } & \text { розвитку [1]-[8]. Тому ВЕБ держави поєднує у } \\ \text { національної безпеки дозволяє стверджувати } & \text { собі певні елементи, на перший погляд, двох } \\ \text { про наявність в безпековому середовищі } & \text { різнобічнихза своєю суттю сфер національної } \\ \text { такої складової як воєнно-економічна } & \text { безпеки: воєнної безпеки (ВБ) та економічної } \\ \text { безпека (ВЕБ), яка може бути визначена як } & \text { безпеки (ЕБ), але їх тісний зв'язок дозволяє } \\ \text { готовність держави забезпечувати такий } & \text { розглядати їх через призму єдиного цілого } \\ \text { рівень розвитку економіки держави, за якого } & \text { елементу безпекового середовища-ВЕБ. }\end{array}$

* Corresponding author: д.в.н., старший науковий співробітник, начальник відділу, e-mail: aosemenenko@ukr.net, ORCID: 0000-0001-6477-3414 
ВЕБ країни може бути представлена як стан захищеності національного економіки держави від зовнішніх та внутрішніх загроз, за якого воно здатна задовольняти економічні потреби воєнної організації (ВОД) для ії будівництва, утримання та подальшого розвитку [1]-[3]. Також ВЕБ держави визначають як вид національної безпеки [1], [7], [9]. ВЕБ може бути представлена як: здатність воєнної економіки стійко підтримувати необхідну воєнну міць та реалізовувати науково-виробничий потенціал воєнної економіки в обсязі та у терміни, що передбачені воєнною доктриною держави, а також як стан національної економіки, за якого має місце достатній розвиток та збереження наукововиробничого потенціалу воєнної економіки, який забезпечує матеріально-технічне оснащення Збройних Сил [1]-[9].

Одним із важливих завдань $€$ не тільки визначення оптимального рівня витрат на оборону, здатних забезпечити необхідний рівень воєнної безпеки за існуючих та потенційних загроз, а й забезпечення стабільного розвитку сфери воєнної безпеки шляхом використання певних елементів економічної складової.
Критерії та показники оцінювання стану ВЕБ повинні надавати можливості усебічного оцінювання розвитку та стійкості національного господарства (у тому числі оборонно-промислового комплексу (ОПК)) [4], [7], [13], як наслідок виникає необхідність формування підходів до розрахунку загального показника інтегрального стану ВЕБ держави, що дозволив би оцінити динаміку змін національної безпеки в цілому, порівняти стани національних господарств різних держав та, можливо, здійснити певне коригування у довгостроковому плануванні для досягнення оптимальних результатів.

Для оцінювання стану ВЕБ України $\epsilon$ необхідним остаточне визначення та впорядкування параметрів, що ії характеризують. Сьогодні щодо визначення механізмів забезпечення ЕБ та ВБ $є$ окремі показники [5], [10], [11] та розроблені методологічні підходи щодо оцінювання рівня економічної безпеки [4].

Тобто постає проблема не тільки у законодавчій відсутності закріплення поняття ВЕБ як складової національної безпеки України, докладного переліку складових елементів та механізмів оцінювання її рівня, а й - загального алгоритму оцінювання її стану.

\section{Аналіз останніх досліджень та публікацій}

Аналіз останніх досліджень і публікацій та ряду документів з цих питань свідчить, що сьогодні питання забезпечення та сталого функціонування ВЕ та ЕБ України розглядаються окремо. У досліджених матеріалах [5], [10], [14] розглянуті відповідні показники та параметри оцінювання їх стану, рівня, наведена методика визначення економічної безпеки та воєнно-економічної безпеки, але останнім часом прогресують погляди щодо спроб виділити елемент воєнно-економічної безпеки у складі ЕБ [3], [5], [14] та проводити оцінювання ії як окремої складової без пекового середовища країни. Тому визначення між ними взаємозв'язків та виокремлення воєнноекономічного елемента як окремої складової національної безпеки набуває все більшої актуальності [1]-[14]. За відсутності остаточно визначених складових параметрів ВЕБ України $є$ доцільною побудова узагальненої лінгвістичної шкали оцінювання їх впливу на стан ВЕБ [5], [12], [15]-[17].

Отже, метою статті $\epsilon$ висвітлення одного із можливих методичних підходів до оцінювання стану воєнно-економічної безпеки України за визначений період за допомогою використання методу нечітких множин та логіко-лінгвістичного підходу [2], [5], [12]-[17].

\section{Постановка завдання}
Метою статті $€$ висвітлення
одного із
можливих
методичних
підходів 
оцінювання стану воєнно-економічної безпеки України за визначений період за допомогою використання методу нечітких множин та логіко-лінгвістичного підходу [2], [5], [12]-[17].

\section{Виклад основного матеріалу}

Рівень ВЕБ може характеризуватися за визначеними критеріями, які повинні відображати економічну та політичну стабільність в суспільстві, цілісність держави, можливість протистояти впливу внутрішніх та зовнішніх загроз, стійкість соціальноекономічної ситуації в державі тощо (мал. 1).

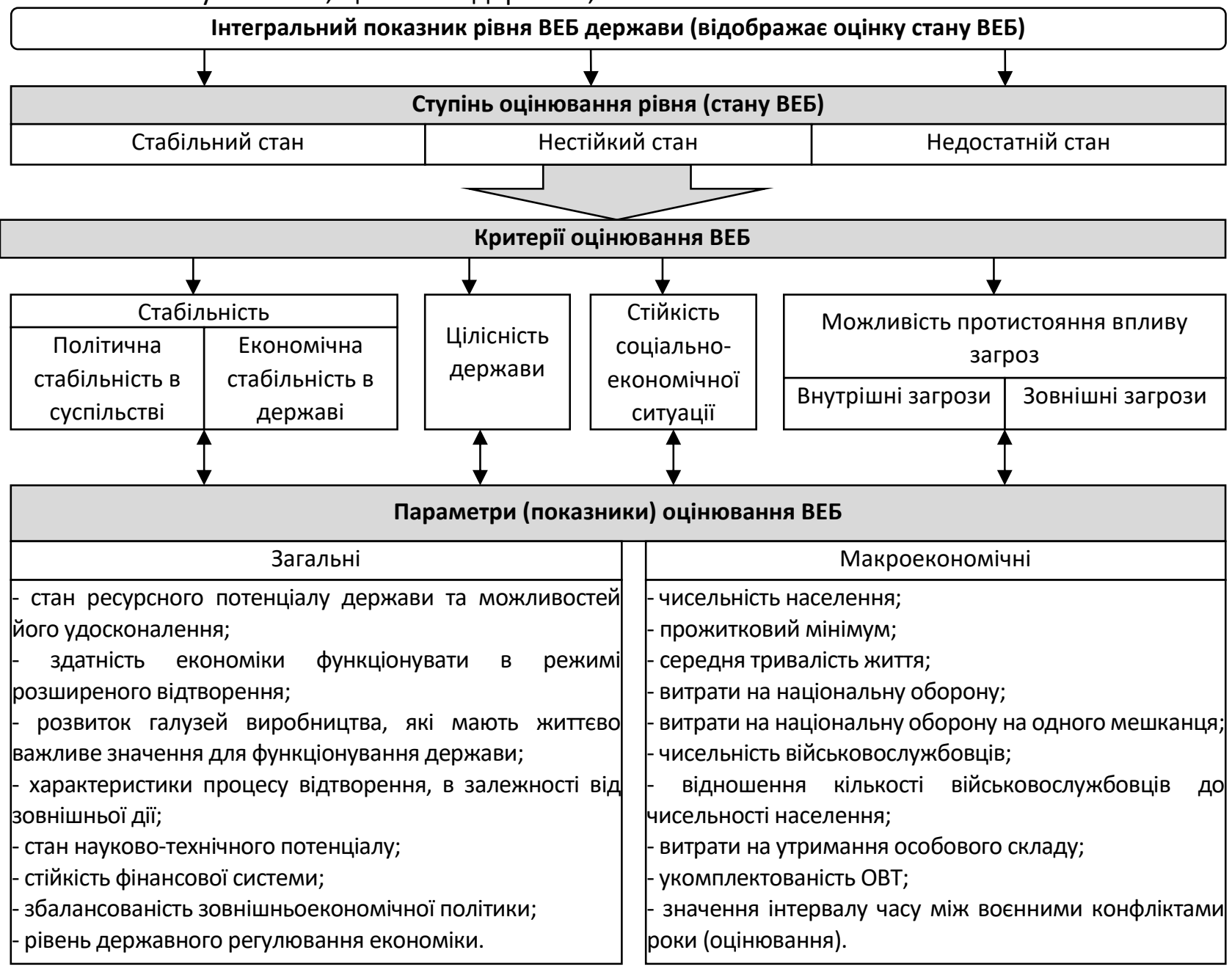

Малюнок 1 - Система показників та критеріїв оцінювання ВЕБ

Процес оцінювання рівня ВЕБ за критеріями передбачає врахування та визначення значень ряду показників (параметрів, індикаторів) головними з яких $\epsilon$ : стан ресурсного потенціалу держави та ії можливостей його удосконалення та розвитку; здатність економіки функціонувати в режимі розширеного відтворення; розвиток галузей виробництва, які мають життєво важливе значення для функціонування держави як в звичайних умовах, так і в стані збройного протиборства; характеристики процесу відтворення, в залежності від зовнішньої дії; стан науково-технічного потенціалу країни; стійкість фінансової системи держави; збалансованість зовнішньоекономічної політики; рівень державного регулювання економіки, який забезпечує їі оптимальне функціонування як в мирних умовах, так i в період військового протиборства.

Необхідно зазначити, що використання підходу, запропонованого у статті, $\epsilon$ раціональним для здійснення узагальненого оцінювання результатів вже діючої системи ВЕБ 
України за відповідний попередній період. За сучасної, остаточно невизначеної, сукупності параметрів, що $€$ складовими ВЕБ України, метод нечітких множин надає можливість здійснити узагальнене оцінювання їі стану.

Нехай $€$ визначена сфера воєнноекономічної безпеки та відомі такі розрахункові дані, як множина внутрішніх параметрів $\left(X=\left\{x_{1}, x_{2}, \ldots, x_{N}\right\}\right), \quad$ множина вихідних параметрів $\left(Y=\left\{y_{1}, y_{2}, \ldots, y_{K}\right\}\right)$ та множина зовнішніх параметрів, що впливають на її стан $\left(Z=\left\{z_{1}, z_{2}, \ldots, z_{M}\right\}\right)$, де $x_{N}, y_{K}, z_{M}-$ числові змінні. За допомогою оцінювання загального впливу цих сукупностей на ВЕБ України можна отримати узагальнену оцінку їі стану $S$ за відповідний період $(t)$ або попередній $S^{\prime}$ (за $t^{\prime}$ ) (мал. 2).

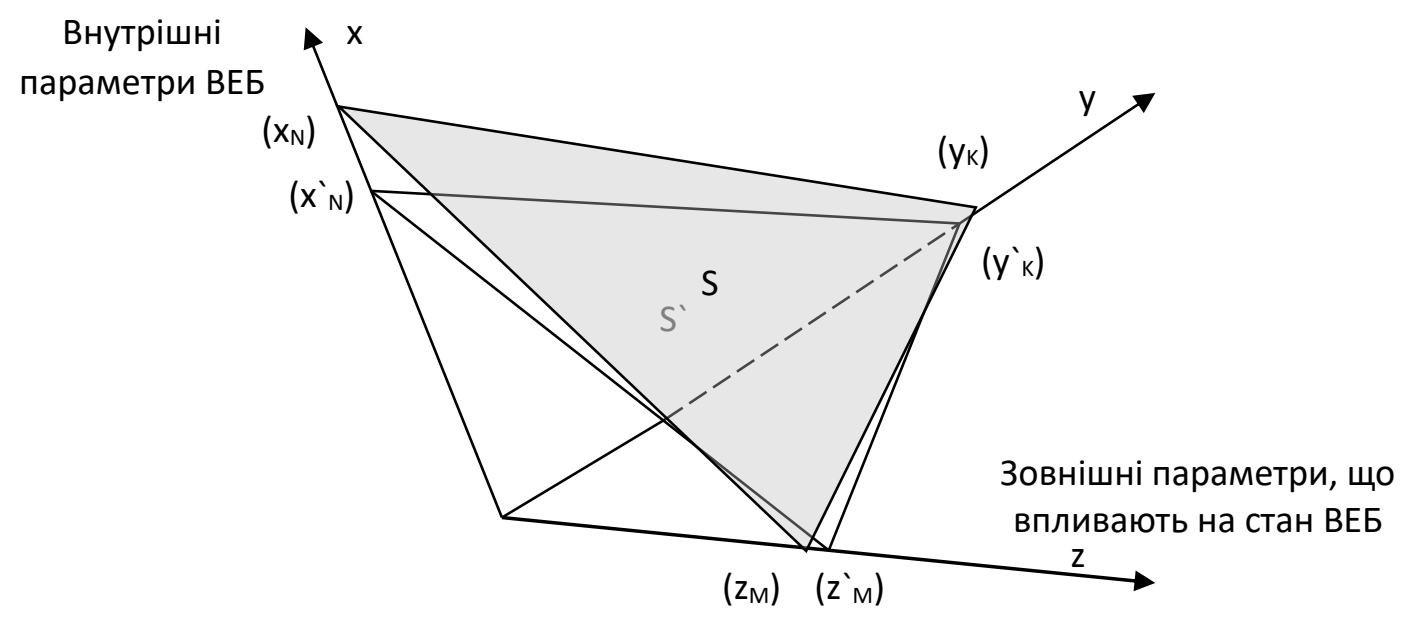

Малюнок 2 - Сукупності параметрів, що характеризують стан ВЕБ України за відповідний період

Система показників ВЕБ держави може також включати макроекономічні показники, часткові соціально-економічні показники, які розкривають та доповнюють головні риси та тенденції розвитку економіки, економічне зростання, конкурентоспроможність національної економіки держави та окремих її галузей, а також економічні показники функціонального та галузевого рівня. Значення цих основних показників (індикаторів) ВЕБ держави, а також їх порогові значення надають можливість аналізу різних складових безпеки національного господарства. Порівняння фактичних значень цих показників 3 пороговими дозволяє робити висновки щодо динаміки змін різних складових ВЕБ держав світу в період їх підготовки до відбиття можливої агресії.

Показники, які впливають на рівень (стан) ВЕБ держави являє собою взаємопов'язану систему показників, кожний 3 яких характеризує певний аспект економічної та воєнної безпеки. Ці показники повинні враховуватися при формування стратегії воєнно-економічного розвитку країни. Показники оцінювання воєнної складової ВЕБ здійснюють безпосередньо вплив на критерій можливості протистояння загрозам та опосередковано пов'язані 3 іншими критеріями. Показники оцінювання економічної складової ВЕБ надають здійснюють вплив на можливості держави щодо всебічного забезпечення розвитку та стійкості національної економіки країни, та її здатності протистояти впливу негативних зовнішніх та внутрішніх факторів, а також визначати ефективність заходів, які практично реалізуються в рамках забезпечення ВЕБ держави.

Загальний інтегральний показник визначення рівня воєнно-економічної безпеки держави, повинен дозволяти оцінювати динаміку змін воєнно-економічної безпеки держави, а також надавати можливість 
порівнювати рівні ВЕБ різних країн.

Більш детальний аналіз показників ВЕБ показує, що одними із необхідних для аналізу параметрів можуть бути: оборонні компоненти виробничої сфери (рівень стану обороннопромислового комплексу, фінішні замкнуті виробничі цикли), оборонні компоненти ресурсної безпеки (рівень забезпечення резервами й запасами матеріальних ресурсів), оборонні компоненти фінансово-економічної безпеки (рівень оборонних видатків у внутрішньому валовому продукті), оборонні компоненти технологічної сфери (рівень технологічної залежності оборонного значення), оборонні компоненти інформаційної безпеки (рівень інформаційної залежності оборонного значення), оборонні компоненти науково-технічної безпеки (рівень науковотехнічної залежності оборонного значення ) [1]-[3], [7], [10], [12] тощо.

Якщо вже $\epsilon$ відомими задані параметри $x_{N} \in X, \quad y_{K} \in Y \quad$ та $z_{M} \in Z$, тоді $є$ відомими й їх значення, що визначають відповідний стан BEБ $(s \in S)$ у певний фіксований момент часу $(t)$. Крім того, для кожного параметра 3 сукупностей $X, Y, Z \in$ відомою його норма та допустиме значення відхилення від норми. Тобто, $\delta x *, \delta y *, \delta z *$ - величини можливих відхилень внутрішніх, вихідних параметрів та відхилень від норми через вплив зовнішніх чинників; $\delta x, \delta y, \delta z$ - величини фактичних відхилень параметрів від норми. Співвідношення цих елементів надають можливість визначити рівень чутливості та стабільності параметричних даних ВЕБ станом на час оцінювання.

Тоді $S$ має містити такі компоненти, як оцінювальні функції внутрішніх, вихідних параметрів та зовнішніх параметрів, що впливають на стан ВЕБ $\left(\eta_{x}(X), \eta_{y}(Y), \eta_{z}(Z)\right)$, а також поточного їі стану $-\eta_{s}^{\text {tec }}(X, Y, Z)=$ $\eta_{s}\left(\eta_{x}(X), \eta_{y}(Y), \eta_{z}(Z)\right)$. Тобто узагальнена оцінка їі стану матиме вигляд такої сукупності: $S=\left\{\eta_{x}(X), \eta_{y}(Y), \eta_{z}(Z), \eta_{s}^{t e c}(X, Y, Z)\right\}$.

Оскільки визначення інтегральної оцінювальної функції стану ВЕБ здійснюється за допомогою використання логіко-лінгвістичного представлення моделі цієї системи, то визначені функції - $\eta_{x}, \eta_{y}, \eta_{z}, \eta_{s}^{\text {tec }}$ та взаємозалежності їх аргументів у цьому випадку представлені у вигляді нечіткого, наприклад, $\eta$ - простору зі шкалами [12]: $\langle T, P, \eta *\rangle$, де $T$-оцінювальна лінгвістична шкала, значення якої визначені на інтервалі від “стабільного стану функціонування" до “критичного стану функціонування", що представлені на інтервалі $[-1 ;+1] ; \quad P$ метрична числова шкала, на якій підлягають зміні фактичні значення параметрів $x_{N}, y_{K}, z_{M}$; $\eta *$ - оцінювальна лінгвістична шкала, елементи якої набирають значення в інтервалі "високий рівень - низький рівень" на проміжку $[-1 ;+1]$. Оптимальним для визначення необхідного стану $є$ виконання твердження, за якого функція приналежності параметрів $\mu(X, Y, Z)=1$ (рис. 3 ).

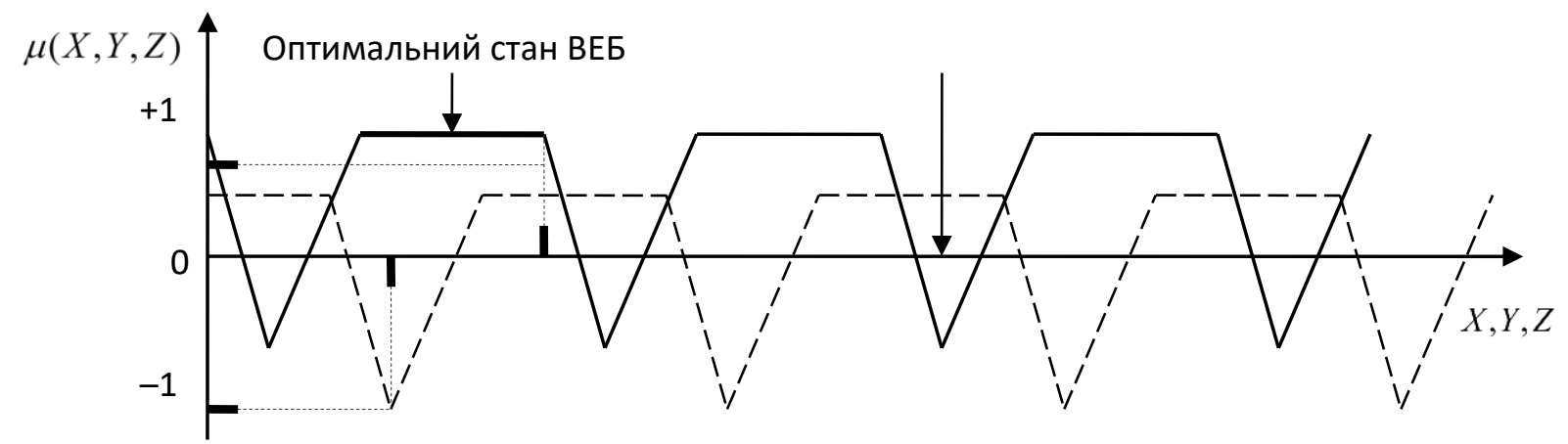

Малюнок 3 Можливі нечіткі множини параметрів ВЕБ за відповідний проміжок часу на визначеному $\eta$ - просторі

Таким чином, оцінювання стану ВЕБ лінгвістичне представлення нечітких задано на нечіткому $\eta$ - просторі як логікохарактеристик, при визначені котрих 
враховуються взаємозв'язки між складовими параметрами ВЕБ [2], [5], [12]-[17].

Наявна можливість, за якої серед множини станів $s \in S \in$ оптимальний стан $S * \in S$, що характеризується нульовим відхиленням поточних параметрів від необхідних для стабільного функціонування системи значень. Оцінювальну функцію такого стану позначимо $\eta_{S}^{*}$. Тоді, оцінювальна функція поточного стану системи ВЕБ матиме вид такої сукупності: $\quad S=$ $\left\{\eta_{s}^{\text {tec }}(X, Y, Z), \eta_{s}^{*}, \rho\left(\eta_{s}^{*}(X), \eta_{s}^{\text {tec }}(X, Y, Z)\right\}\right.$,

де $\rho\left(\eta_{s}^{*}(X), \eta_{s}^{\text {tec }}(X, Y, Z)\right)-$ функція, що виражає рівень щільності функціонування поточного та оптимального станів ВЕБ.

Тобто, для визначення алгоритму

\section{Блок упорядкування параметричних даних ВЕБ}

$(x, y, z, \xi, v$ тощо)

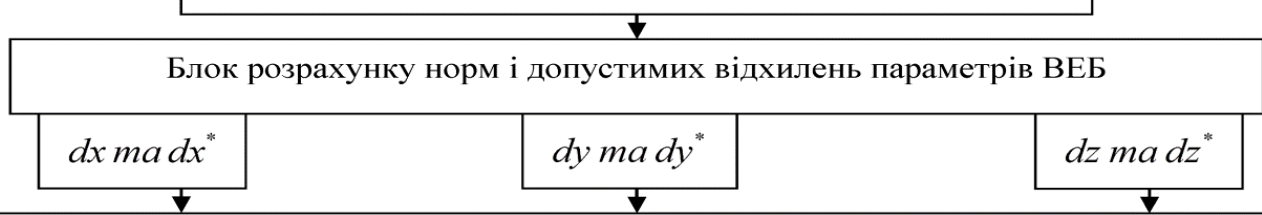

Блок визначення оцінювальної функції параметрів внутрішніх, вихідних та параметрів, що впливають на стан ВЕБ відповідно

$\eta_{x}(X)=\oint_{\downarrow}\left(\eta^{*}{ }_{x}(X) ; \mu(x)\right) \quad \quad \eta_{y}(Y)=\oint_{\downarrow}\left(\eta^{*}{ }_{y}(Y) ; \mu(y)\right) \quad \quad \eta_{z}(Z)=\oint\left(\eta^{*}{ }_{z}(Z) ; \mu(z)\right)$

Блок розрахунку інтегральної оцінювальної функції поточного стану ВЕБ

$\eta_{s}^{t e c}(X, Y, Z)=\oint\left(\eta_{s}\left(\eta_{x}(X), \eta_{y}(Y), \eta_{z}(Z)\right)\right)$ та функції оптимального стану ВЕБ

Блок визначення функції, що виражає рівень наближеності поточного та оптимального станів

$$
\rho\left(\eta_{s}^{\text {tec }}(X, Y, Z) ; \eta_{s}^{*}(X, Y, Z)\right)=\oint\left(\rho\left(\eta_{s}^{\text {tec }}(X, Y, Z) ; \eta_{s}^{*}(X, Y, Z)\right)\right)
$$

Блок визначення інтегральної оціночної функції системи ВЕБ за допомогою інтеграла Стілтьєса

$$
\oint\left(\rho\left(\eta_{s}^{*}, \eta_{s}^{t e c}(X, Y, Z)\right)\right)=\int_{t=0}^{t=2} \rho\left(\eta_{s}^{*}, \eta_{s}^{t e c}(X, Y, Z)\right) t d t
$$

Малюнок 4 - Алгоритм визначення інтегральної функції стану ВЕБ України

Як і раніше, під час визначення оцінювальної функції $\eta_{x}(X), \eta_{y}(Y), \eta_{z}(Z), \quad$ введемо нечіткий тривимірний $\rho$ - простір у межах шкали $\langle T, P, \rho\rangle$, де $T, P$ відображають показники відповідних шкал $\eta$ - простору, а $\rho$ шкала визначає лінгвістичну змінну міри близькості станів, що визначається на інтервалі $[-1 ;+1]$ від “повного збігу" $(\rho=+1)$ до "відсутності зв'язку" $(\rho=-1)$ відповідно.

Тобто, для отримання результату оцінювання системи ВЕБ України наведені вище результати можна структурувати в алгоритм розрахунку інтегральної оцінювальної функції системи ВЕБ України (рис. 4).У введеному $\rho$-просторі 3 
урахуванням (2) інтегральної оцінки близькості існування станів пропонується визначити за допомогою інтеграла Стілтьєса [13]:

$$
\Omega\left(\rho\left(s_{i}, s_{j}\right)\right)=\int_{t=0}^{t=2} \rho\left(s_{i}, s_{j}\right) t d t .
$$

Тоді для визначення інтегральної оцінювальної функції системи в (3) замість $s_{i}$ необхідно підставити $\eta_{s}^{*}$, а замість $s_{j}-$ $\eta_{S}^{t e c}(X, Y, Z)$ :

$$
\begin{aligned}
\oint\left[\rho\left(\eta_{s}^{*}, \eta_{s}^{t e c}(X, Y, Z)\right)\right] \\
=\int_{t=0}^{t=2} \rho\left(\eta_{s}^{*}, \eta_{s}^{t e c}(X, Y, Z)\right) t d t
\end{aligned}
$$

За використання логіко-лінгвістичного підходу при розробленні цього підходу до оцінювання системи ВЕБ України остаточний результат зазначеної інтегральної оцінювальної функції коливається у межах $[-1 ;+1]$ від "нормального стану функціонування" до “критичного стану функціонування" системи.

\section{Висновки}

Запропонований методичний підхід до оцінювання рівня ВЕБ країни базується на використанні логіко-лінгвістичного підходу, що застосовується для загального оцінювання систем та не вимагає отримання чітких числових даних. Результати, що отримані за допомогою такого аналізу дозволяють приймати важливі швидкі стратегічні рішення без використання кількісних оцінок.

Використання цього підходу та методу нечітких множин у побудові алгоритму визначення інтегральної оцінювальної функції стану ВЕБ України надало змогу розробити універсальний узагальнюючий підхід до оцінювання стану ВЕБ без використання кількісних показників за наявності нечіткої сукупності її складових параметрів.

Подальшого системного аналізу потребують питання чіткої структуризації параметрів (складових) ВЕБ України, їх класифікація, розроблення моделі впливу зовнішніх чинників (у тому числі й загроз) на формування i розвиток ВЕБ України, а також розроблення Методики розрахунку їі рівня.

Подальшого системного аналізу потребують питання чіткої структуризації параметрів (складових) ВЕБ України, їх класифікація, розроблення моделі впливу зовнішніх чинників (у тому числі й загроз) на формування i розвиток ВЕБ України, а також розроблення Методики розрахунку їі рівня.

\section{Список використаних джерел}

1. Семененко О. М., Бойко Р. В., Водчиць О. Г., Кострач В. В., Бердочник А.Д. (2016) Основні аспекти воєнно-економічної безпеки України та можливі шляхи їі забезпечення на середньострокову перспективу (2016-2020pp.). Системи озброєння і військова техніка: щокварт. наук. журн. Харків: ХНУПС, №3 (47). С.159163.

2. Постникова, Л.П. Теория вероятностей и математическая статистика.: учеб.-метод. пос. / Л. П. Постникова, Е. В. Сумин. Москва: НИЯУ МИФИ, 2010. 84 с.

3. Мунтіян, В.І. Економічна безпека України / І. В. Мунтіян. Київ: КВІЦ, 1999. С. 135-152.

4. Семененко О. М., К Кострач В. В., Ліманська
М. А., Іванов В. Л. (2016) Оборонні аспекти економічної стратегії України в рамках забезпечення достатнього рівня воєнноекономічної безпеки. 3б. наук. пр. ЦНДІ ЗС України. № 1 (75). С. 297-308.

5. Семененко О. М., Добровольський Ю. Б., Кострач В. В., Малиш А. Г. (2016) Нечіткомножинна математична модель побудови шкали оцінювання рівня воєнноекономічної безпеки. 3б. наук. пр. ЦНДІ ЗС України. № 2 (76). С. 235-248.

6. Лодзянов, А. Д., Сніжко Г. Т. (2004) Воєнноекономічна безпека в умовах реформування оборонної сфери України. Стратегічна панорама. 2004. № 1. С. 65-72.

7. Маслюк, В.Е. Сутність воєнно-економічної 
безпеки та ключові напрямки ї̈ забезпечення в Україні URL: http://www.google.com. ua/url?sa=t\&rct=j\&q=\&esrc.

8. Ольшевський, В. Й.

Воєнноекономічна безпека: теорія і практика. Наука і оборона. № 3. С. 36-41.

9. Гордиенко Д.В., Хохлов А.С. Военноэкономическая безопасность государства. Монография. Под ред. доктора военных наук, доцента Д.В. Гордиенко. М. Военная академия Генерального штаба ВС РФ, 2008, $288 \mathrm{c}$.

10. Пожаров, А. И. (2000) Показатели и критерии военно-економической безопасности. Военная мысль. 2000. № 6. С. 26-34.

11. Новікова, О. Ф. Економічна безпека: концептуальні визначення та механізм забезпечення: монографія / О.Ф. Новікова, Р. В. Покотиленко. Донецьк: Ін-т ек-ки промті НАН України, 2006. 54 с.

12. Новосельцев, В. И. Теоретические основы системного анализа: учеб.-метод. пос./
В. И. Новосельцев,
Б. B. Тарасов,
B. K. Голиков. Москва: Мир, 2005. С. 230-235.

13. Богданов, С. А. (2009) Военно-экономическая составляющая безопасности страны. Весник акад. наук РФ. 2009. № 2. С. 36-48.

14. Семененко О. М., Бойко Р. В., Водчиць О. Г., Остапець О. М., Кремешний О.І. (2013) Методичний підхід щодо оцінювання рівня воєнно-економічної безпеки держави на основі оцінок рівнів забезпеченості ресурсами. Системи озброєння і військова техніка: щокварт. наук. журн. Харків: ХНУПС. № 4 (36). С. 156-162.

15. Заде, Л. Понятие лингвистической переменной и ёё применение к принятию приближённых решений. Москва: Мир, 1976.

16. Фишберн, П. Теория полезности для принятия решений. Москва: Наука,1978.

17. Василевич, Л.Ф. Теория риска. Киев: КІІМ, КБШ, 2002.

\title{
Логико-лингвистическая модель оценивания состояния военно-экономической безопасности государства
}

\author{
Олег Семененко * А; Ирина Чернышова А; Людмила Добровольская ${ }^{\text {; }}$ \\ Костантин Харитонов ${ }^{\text {; }}$ Иван Мотрунич ${ }^{\mathrm{D}}$ \\ *Corresponding author: д.в.н., с.н.с., заведующий отделом, e-mail: aosemenenko@ukr.net, ORCID: 0000-0001-6477-3414 \\ А Центральний науково-дослідний інститут Збройних Сил України, Повітрофлотський проспект, 28, м. Київ-049, 03049, Україна

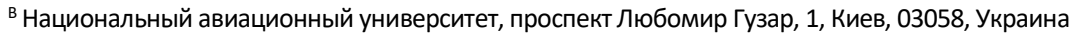 \\ с Командование войск связи и кибербезопасности Вооруженных Сил Украины, пр-кт Воздухофлотский, 6, г. Киев, 03168, Украина \\ D Центр обеспечения служебной деятельности МО и ГШ ВС Украины, пр-кт Воздухофлотский, 6, г. Киев, 03168, Украина
}

\begin{abstract}
Аннотация
Современные тенденции развития теории и практики формирования национальных интересов государства и оценивание состояния их защищённости показывает, что одним из определяющих элементов современной среды безопасности для любой страны есть состояние развития её военной и экономической составляющих. Тесная связь этих двух составляющих национальной безопасности Украины разрешает их объединить в единое понятие - военно-экономическая безопасность страны. Сегодня, военно-экономическую безопасность можно рассматривать как состояние защищенности национальной экономики страны от внешних и внутренних угроз, при которых она способна обеспечить экономические потребности военной организации для её строительства, содержания и развития с целью обеспечить необходимый уровень защиты национальных интересов Украины в целому. В статье авторами представлен один из возможных подходов к оцениванию состояния военно-экономической безопасности страны при наличии неопределенной совокупности входных $и$ выходных параметров с помощью использования метода нечетких множеств и логико-лингвистического подхода. Применение такого подхода даст возможность сформировать общие оценки состояния военно-экономической безопасности государства с целью принятия соответствующих
\end{abstract}


управленческих решений по дальнейшему ее развитию, а также применение теории нечетких множеств во время оценивания позволит соотносить чувствительность и стабильность принятых решений к возможным изменениям входных данных.

Ключевые слова: военная безопасность, экономическая безопасность, военноэкономическая безопасность, оборонные компоненты, лингвистическая шкала, лингвистическая переменная, интегральная функция, логико-лингвистический подход.

\title{
Logical-linguistic model of condition assessment military and economic security of the state
}

\author{
Oleg Semenenko * A; Iryna Chernyshova A; Liudmyla Dobrovolska ${ }^{B}$; \\ Konstantin Kharitonov ${ }^{\text {; }}$; Ivan Motrunych ${ }^{\mathrm{D}}$ \\ *Corresponding author: Dr., Senior Research, e-mail: aosemenenko@ukr.net, ORCID: 0000-0001-6477-3414 \\ ${ }^{A}$ Central Research Institute of the Armed Forces of Ukraine, 28, Povitroflotskyi Av., Kyiv-049, 03049, Ukraine \\ ${ }^{B}$ National Aviation University, 1, Lubomyr Husar Ave., Kyiv, 03058, Ukraine \\ ' Command of the Communications and Cyber Security Forces of the Armed Forces of Ukraine, 6, Povitroflotskyi Av., Kyiv, 03168, Ukraine \\ D Service Support Center of the Ministry of Defense and the General Staff of the Armed Forces of Ukraine, 6, Povitroflotskyi Av., \\ Kyiv, 03168, Ukraine
}

\begin{abstract}
Modern trends in the development of the theory and practice of the formation of the national interests of the state and the assessment of the state of their security show that one of the defining elements of the modern security environment for any country is the state of development of its military and economic components. The close connection of these two components of Ukraine's national security allows them to be combined into a single concept - the military-economic security of the country. Today, military-economic security can be considered as the state of protection of the national economy of the country from external and internal threats, in which it is able to meet the economic needs of a military organization for its construction, maintenance and development in order to ensure the necessary level of protection of the national interests of Ukraine as a whole. In the article, the authors present one of the possible approaches to assessing the state of the country's military-economic security in the presence of an indefinite set of input and output parameters using the method of fuzzy sets and a logical-linguistic approach. The application of this approach will make it possible to form general assessments of the state of the military-economic security of the state in order to make appropriate managerial decisions on its further development, as well as the use of fuzzy set theory during the assessment will make it possible to correlate the sensitivity and stability of the decisions made to possible changes in the input data.
\end{abstract}

Keywords: military security, economic security, military-economic security, defense components, linguistic scale, linguistic variable, integral function, logical-linguistic approach.

\section{References}

1. Semenenko O. M., Boyko R. V., Vodchits O. G., Kostrach V. V., Berdochnik A. D. (2016) The main aspects of the military-economic security of Ukraine and the potential for security in the middle-line perspective (2016-2020). Systemy ozbroiennia i viiskova tekhnika: quarterly sciences journal. Kharkiv: KhNUPS, № 3 (47). S. 159-163.

2. Postnikova, L. P., Sumin E. V. Probability theory and mathematical statistics: study guide. pos. Moscow: NIIaU MIFI, 2010.84 s.

3. Muntian, V. I. Ekonomichna bezpeka of Ukraine. Kyiv KVITS, 1999. P. 135-152.

4. Semenenko O. M, Kostrach V. V., Lymanska M. A., Ivanov V. L. Defense aspects of the economic strategy of Ukraine within the framework of securing a sufficient level of military and economic security // Coll. Science. 
etc. Central Research Institute of the Armed Forces of Ukraine. Kyiv. 2016. № 1 (75). P. 297308.

5. Semenenko O. M., Dobrovolsky Yu. B., Kostrach V. V., Malysh A. G. Fuzzy-plural mathematical model for constructing a scale for assessing the level of military and economic security // Coll. Science. etc. Central Research Institute of the Armed Forces of Ukraine. Kyiv. 2016. № 2 (76). P. 235-248.

6. Lodzyanov, A.D., Snizhko G.T. (2004) Militaryeconomic security in the conditions of reforming the defense sphere of Ukraine. Stratehichna panorama. № 1. P. 65-72.

7. Maslyuk, V. E. The essence of military and economic security and key areas of its provision in Ukraine. URL: http://www.google.com.ua/ url?sa=t\&rct=j\&q=\&esrc.

8. Olshevsky, V.Y. (1999) Military and economic security: theory and practice. Nauka i oborona. Kyiv. № 3. P. 36-41.

9. Gordienko D. V., Khokhlov A. S. Military and economic security of the state. Monograph. Ed. Doctor of Military Sciences, Associate Professor D.V. Gordienko. M. Military Academy of the General Staff of the RF Armed Forces, 2008, $288 \mathrm{p}$.

10. Pozharov, A. I. (2000) Indicators and criteria of military-economic security. Voennaia mysl.
№ 6. P. 26-34.

11. Novikova, O.F. Economic security: conceptual definitions and mechanism of provision: monograph / O.F. Novikova, R.V. Pokotylenko. Donetsk: Inst. Of Industrial Sciences of the National Academy of Sciences of Ukraine, 2006. $54 \mathrm{p}$.

12. Theoretical foundations of system analysis: study guide. pos. / V. I. Novoseltsev, B. V. Tarasov, V. K. Golikov. Moscow: Mir, 2005. P. 230-235

13. Bogdanov, S. A. (2009) The military-economic component of the country's security. Sciences RF. № 2. P. 36-48.

14. Semenenko O. M., Boyko R. V., Vodchyts O. G., Ostapets O. M., Kremeshny O. I. (2013) Methodical approach to assessing the level of military and economic security of the state on the basis of assessments of levels of resource security // Systemy ozbroiennia i viiskova tekhnika: quarterly sciences journal. Kharkiv: KhNUPS, № 4 (36). P. 156-162.

15. Zade, L. The concept of a linguistic variable and its application to making approximate decisions. Moscow: Mir, 1976.

16. Fishburne, P. Utility theory for decision making. Moscow: Nauka, 1978.

17. Vasilevich, L.F. Risk theory. Kyiv: KIIM, KBSh,2002. 